\title{
Terminal values and meaning in life among university students with varied levels of altruism in the present period of socio-cultural change
}

\section{ABSTRACT}

The author of this paper, interested in the issues of values preference, meaning in life and altruism among university students has attempted to show a relation between them in the present period of clearly noticeable socio-cultural change. The study was conducted in 2009-2010 in Kraków among university students. The age of the respondents ranged from 21 to 25.200 sets of correctly completed questionnaires were used for the results analysis.

In order to show values preference among university students Rokeach's Value Survey (RVS) was used. The level of a sense of meaning in life was measured by means of Crumbaugh and Maholick's Purpose in Life Test (PLT). Moreover, Śliwak's Questionnaire of Altruism (A-N) was applied to measure the level of altruism.

It was found that students with a high level of altruism are accompanied by a higher level of meaning in life than students with a low level thereof. Terminal values significantly correlate with meaning in life in groups of students with a high and low level of altruism. Among terminal values, values personal in character appear to be more strongly related to meaning in life than values social in character.

KEYWORDS: altruism, meaning in life, socio-cultural change, terminal values

* Correspondence regarding the paper should be sent to: Stanisław Głaz, Jesuit University Ignatianum in Krakow, ul. Kopernika 26, 31-201 Kraków, e-mail: zjglaz@cyf-kr.edu.pl 


\section{INTRODUCTION}

In the present period of socio-cultural change also many changes in young people's lives are clearly visible. They are frequently related to an attitude to oneself, towards other people and present social challenges. The process of attitude change in students is connected with the country's rapid change in political system, change in social behaviour, globalisation (Mariański, 2002; Piontek, 2008), a lack of a sense of meaning in life (Oliynichuk, Popielski, 2008) as well as a lack of feeling of safety (Głaz, 2011). Many researchers attempt to comprehend this complex situation and the future of young university students by providing relevant knowledge on the subject matter (Blanchard, 1998; Kość, 2008).

The author, interested in values, a sense of meaning in life and altruism in university students' lives, has attempted to show in this paper a relationship between them in the present period of clearly noticeable socio-cultural change.

A human being typically evaluates and makes assessments, seeks values and acts in accordance with them. What are values? A value is commonly conceived of as any aim or object of aspiration for a human being. Values consist in both material objects and people, social groups, institutions or ideas. A value is considered as something that directs human behaviour in a given culture, that is respectable and desirable owing to a certain goal (Aronson, Wilson, Akert, 1997; Opoczyńska, 1995). Values perform an important role. Namely, they regulate individual and community lives in a given society (Oleś, 2003). In this paper, Rokeach's definition of value was applied (1973). According to Rokeach, the value concept is a constant belief that a specific mode of conduct or end (ultimate) state of existence is personally and socially superior to an opposite or converse mode of conduct or end state of existence. Rokeach distinguished two kinds of values: terminal, which are personal and social in character and which define the end state of human desires and aspirations (such as personal freedom, salva- 
tion), and instrumental values, which are moral in character and denote competency and which are seen as desirable modes of conduct (e.g. helpfulness, self-control). The instrumental values serve to achieve the terminal values. Particular values exist within an orderly system. Hence a human ability to point to values which are higher or lower in his or her hierarchy of values.

A human being does not only seek pleasure in life, but mainly accomplishes values and aims at discovering meaning in his or her life (Głaz, 2002; Popielski, 2008). The subject of meaning in life can be considered on two levels: as one of the human needs and as a state of meaning in life, i.e. a sense of meaning in life (Popielski, 1987; Frankl, 1978). A man fulfills his or her meaning in life by striving for perfection within a certain community (Adler, 1964). Meaning in life is up-dated by self-accomplishment of 'one's own potentialities' (Maslow, 1968). It is supposed to be revealed in pursuing one's own interests (Rogers, 1983; May, 1981). Meaning in life is related to 'will of the sense', which constitutes in a dynamic tendency motivating a man to take action in order to fulfill his or her needs (Lukas, 1990). The meaning has got its specific features (Frankl, 1987): being common - as it appears in any everyday situation and in every man's life; being particular - in a given situation it can be ascribed to a particular person; being unique and inimitable - what has not been done cannot be done ever again; continuity and changeability - every day expects a man with a different sense, and some sense always exists.

The concept of altruism has relevance to the matter at hand. Altruism relates to supporting other people in multiplying good. According to researchers, there are several reasons why one helps others in life. Among them are: selfish motivation, which consists in a will to be rewarded and involves a desire for the favour to be reciprocated; moral motivation, resulting from being loyal to internalised values and principles; and altruistic motivation, which 
means a desire to provide benefit for others, cheer them up or relieve their pain (Piliavin, Charng, 1990; Miller, 2008).

Until recently, altruism was perceived as a rather unrealistic moral postulate; nowadays, however, it seems to be necessary for normal functioning of an individual and social groups. Altruistic behaviour is part and parcel of everyday life. People typically do not hesitate to devote their time, property and health for the welfare of other individuals and groups (Olsen, 1991). An example of such conduct are acts of heroism for others in wartime, acts meant to save people in emergency situations, or ordinary, prosocial acts directed toward strangers (Jarymowicz, 2004).

In the present paper the concept of altruism as defined by Śliwak (2002) was applied. He relates to Karyłowski's definition of altruism (1982), who seems to think that selfless action to the benefit of others results from endo- and esoteric factors, considered more as a characteristic - which means relatively permanent human traits - rather than a state. Therefore, Śliwak understands altruism as conscious and voluntary action to the benefit of others. Such a person has no expectation of any external reward or distinction in return and his or her act of helping others is a value itself.

\section{RESEARCH AIMS AND HYPOTHESIS}

The analysis of the subject reveals that students vary with regard to the way they accomplish the need of meaning in life and subjective satisfaction resulting from this accomplishment (Lukas, 1990). They also appear to differ as far as values preference (Frankl, 1971; Jones, 2001) and modes of selfless behaviour to the benefit of others are concerned (Śliwak, 2002; Głaz, 2010).

There has been substantial investigation into the relationship between values and meaning in life and altruism. Brzozowski (2007) aimed at showing a model of value hierarchy which would 
have a stronger connection than a typical hierarchy with personal indicators of social adaptation and mental health. The research by Czerniawska (2000) finds that aggressive adolescents have more respect for hedonistic-independent values, whereas adolescents well adapted socially respect moral and religious values more. Comprehensive school (high school) students are more trusting of others and more socially active than vocational school students. Other research proves a significant correlation between values and conscience sensitivity (Buksik, 2003). People with a low level of conscience sensitivity have more respect for values such as an exciting life or a comfortable life, whereas those with a high level of conscience sensitivity value for instance cleanliness and salvation. Cieciach (2006) succeeded in showing the peculiarity of the preference of values related to family life. With an increase in preference of patriotic values - connected with an increase in preference of religious values - the preference of value family security also increases. When the level of acceptance of the belief that human nature is inherently good - connected with an increase in respect for moral values - grows, the preference of value family security also grows. The decrease in the level of acceptance of the belief that democracy is a good system - connected with an increase in preference of patriotic values - makes the value family security more significant.

There is a connection between the concept of values and a sense of meaning in life and altruism. People with a high level of a sense of meaning in life tend to prefer values personal and moral in character (Popielski, 2008). They seem to be more open to other people and to new experiences than those with a low level of a sense of meaning in life (Głaz, 2002). People with a high level of altruism reveal a greater sense of responsibility, a high level of moral life and an orderly system of values (Śliwak, 2001). Research by Śliwak and Leszczuk (1994) indicates a significant correlation between a high level of altruism and a perfect image of oneself. In a group of people with a high level of altruism the indicator of 
a sense of meaning in life was higher than in a group of people with a low level of altruism (Śliwak, 2002). The emotional sphere is also significantly related to altruism, as suggested by findings of the research carried out by Kruger (2001), Korchmaros and Kenny (2001), who focused on assessing the level of altruism among their relatives.

The analysis of the subject indicates that meaning in life is related to values and altruism. The existence of this relation implies that people with a high level of altruism should be accompanied by a higher level of meaning in life and a different kind of values than those with a low level of altruism. Various research studies also suggest that different values may significantly affect meaning in life in people with a high level of altruism than the values in a group with a low level of altruism.

Hence a question arises: Who should the study be conducted among? In the period of socio-economic change, seeking new solutions in an individual and societal life, university students' departing from existing values in favour of the newly-arisen ones, it seem essential to carry out such a study among university students (Dróżdż, 2003; Loewenthal, 2002).

As mentioned before, values perform an important role in an individual and societal life (Oleś, 2003). Values can be considered in their terminal dimension, when they describe the end state of human aspirations and desires and are personal and social in character. A human being achieves self-actualisation by discovering values and meaning in life and their accomplishment. Meaning in life can be perceived as a need of meaning in life and a state of meaning in life. A state of meaning in life is connected with a subjective experience of a sense of one's own life and an emotional factor is a greater part of it. A person with a great sense of meaning in life is satisfied with his or her life and is often creative. A need of meaning in life, however, is accomplished by pursuit of goals and their attainment and by affirmation of one's own life (Frankl, 1977). The aspiration factor prevails here. Altru- 
ism seen as selfless concern for another person is characterised by a lot of emotionality as well as cognitive-social elements (Łobocki, 1998). It is assumed that altruistic behaviour is a conscious act and a sign of readiness to provide support, including accepting the consequences of such behaviour. It is a mode of conduct driven by selflessness, which means with no expectation of compensation or benefits. It is a set of voluntary actions to the benefit of other people (Karyłowski, 1982; Śliwak, 2001).

Hence setting the study question in the present paper suggests establishing a relationship between particular indicators of human life, such as: (1) terminal values personal and social in character, and (2) meaning in life expressed by: (a) a sense of meaning in life (SZ), which describes the state of meaning in life in a human life, (b) attainment of life goals (CZ) and (c) affirmation of one's own life (DZ), which are a sign of accomplishment of the need of meaning in life, in groups of students with a high $(\mathrm{H})$ and low (L) level of altruism.

The aim of the study encouraged the author of this paper to seek answers to the following study questions:

1. Does the level of altruism differentiate the variables: (a) relating to terminal values personal and social in character; (b) and relating to meaning in life: a sense of meaning in life - as a state of meaning in life, attainment of life goals and affirmation of one's own life - as a sign of accomplishment of the need of meaning in life?

Carrying out a threshold classification of altruism suggests that students are accompanied by specific terminal values personal and social in character and by a level of meaning in life depending on the intensity of altruism.

2. Which variables relating to terminal values of personal and social dimension, to what extent and in which order account for the variance of the dependent variables, i.e. a sense of meaning in life (as a state of meaning in life), attainment of goals and affirmation of one's own life (as a sign of accomplishment of 
the need of meaning in life) in groups of students with a high $(\mathrm{H})$ and low $(\mathrm{L})$ level of altruism?

The study question indicates showing the influence of the value predicator, i.e. terminal values personal and social in character, on meaning in life, taking into consideration the intensity of altruism.

The study questions suggest posing the following hypothesis:

1. Students with a high level of altruism reveal a higher level of meaning in life, i.e. a sense of meaning in life - as a state of meaning in life, attainment of goals and affirmation of one's own life - as a sign of accomplishment of the need of meaning in life than students with a low level of altruism.

2. Students with a high level of altruism prefer more (out of terminal values) values social in character, rather than personal in character.

3. Students with a low level of altruism prefer more (out of terminal values) values personal in character rather than social in character.

4. Terminal values personal in character contribute more to explaining the variance of meaning in life - as a state of meaning in life - in a group of students with a high level of altruism, whereas in a group with a low level of altruism - values social in character.

5. Values social in character contribute more to explaining the variance of meaning in life, i.e. attainment of life goals and affirmation of one's own life, which are a sign of accomplishment of the need of meaning in life, in a group of students with a high level of altruism, whereas in a group of students with a low level of altruism - values of personal dimension. 


\section{METHODS APPLIED AND THEIR CHARACTERISTICS}

The aim of the study determined the choice of appropriate tools. The author applied such research tools available to present-day psychology which enable to establish the levels of the afore-mentioned variables and show their correlation in students' lives.

a) In order to determine young people's preferences concerning their values, the Rokeach Value Survey (RVS) was applied. It consists of two sub-scales. Each sub-scale consists of 18 values. One of the sub-scales is used to measure the preference of ultimate values (intrapersonal and interpersonal), i.e. the most important goals, whereas the other sub-scale is used to order instrumental values (moral and competence), which are the most general standards of conduct. Rokeach estimated the permanence of each value (test reliability) by the test-retest method $(\mathrm{N}=250)$ and the scores for ultimate values were coefficients ranging from 0.51 to 0.88 , and for instrumental values from 0.45 to 0.70 . The ranking correlation coefficients between the Polish and American versions of the instrumental and ultimate value scales were 0.99 and 0.98 respectively. The (r) Pearson coefficients for individual positions equaled: in case of ultimate values - on average 0.79 , and for instrumental values - on average 0.68 (Rokeach, 1973). In the present paper only the scale of terminal values was used.

b) The Purpose in Life Test (PLT) by J. Crumbaugh $\mathcal{E}$ L. Maholick. The test was constructed on the basis of Frankl's (1971) existential frustration theory and noogenic neurosis. The starting point was an operational understanding of meaning in life. The test consists of three parts. In the first part there is a seven-grade scale comprised of 20 statements. Number 1 stands for the optimal intensity of the lack of meaning in life, whereas number 7 indicates the strongest intensity of a positive attitude to life. In the present study the first part of the questionnaire was used. The classification of the statements in this first part was carried 
out in the following way: All the statements were grouped in three sets. These are: a sense of meaning in life (SZ) - this factor describes the level of intensity of a sense of meaning in life (inner satisfaction); attainment of life goals (CZ) - it describes a sign of accomplishment of the need of meaning in life; and the last factor relates to affirmation of life (DZ), and it also describes the sign of accomplishment of the need of meaning in life. Cronbach's alpha coefficient of internal consistency for consecutive sub-scales ranges from 0.88 to 0.92 . The reliability indicator calculated using the $\mathrm{r}$ Pearson for the present, revised list of statements is 0.81 , and 0.90 after verification with the Spearman-Brown formula (Popielski, 1987).

c) J. Śliwak's Altruism Questionnaire (A-N). To measure the level of readiness for selfless action to the benefit of others with no expectation of external reinforcement, Śliwak's Altruism Questionnaire (A-N) was used. It consists of two parts. Part One comprises 9 stories followed by a set of 6 ready-made categories of possible reactions (answers), which constitute various levels of intensity of altruism. The stories depict a situation in which an imaginary character is faced with a moral dilemma and is supposed to make a decision whether to help the person in need or not. Part Two includes 8 stories. The respondents' task is to express their opinion using a 7-grade Likert-type scale, depending on the extent they agree or disagree with the decision taken by the protagonist of each story. The grand total is the sum of the sub-totals scored by a person in Part One and Two. It fits on the scale between 17-110 points. The lowest score means lack of altruism, whereas the highest score indicates the highest level of altruism. The reliability of the Questionnaire was tested with the method of absolute stability, which means testing the same group of subjects twice, separated by 14 days. The $r$ Pearson correlation coefficient for the whole scale for Part One equals 0.89, and for part two 0.75 (Śliwak, 2001). 


\section{RESEARCH STRATEGY}

Scientists are well-acquainted with the issues of values, meaning in life and altruism. Nevertheless, there is a visible lack of more detailed investigations in this field, especially in the present period of socio-cultural change, which encourages further studies. Alongside the aforementioned methodological principles at hand, a further strategy of this study was outlined.

The aim of the present study was:

a) to show: (1) preference of terminal values personal and social in character, and to define (2) the level of meaning in life: which means a sense of meaning in life (SZ) - as a state of meaning in life, attainment of life goals (CZ), affirmation of one's own life (DZ) - as a sign of accomplishment of the need of meaning in life, in groups of students with a high $(\mathrm{H})$ and low $(\mathrm{L})$ level of altruism;

b) to show the relationship between (1) terminal values personal and social in character and (2) meaning in life, which means a sense of meaning in life (SZ) - as a state of meaning in life, attainment of goals (CZ), affirmation of one's own life (DZ) - as a sign of accomplishment of the need of meaning in life, in groups of students with a high $(\mathrm{H})$ and low $(\mathrm{L})$ level of altruism.

The variable related to altruism was dichotomized. The values obtained in the Altruism Questionnaire (A-N) provided the criterion for the dichotomy. Two groups of people were formed: with low $(\mathrm{L})$ and high $(\mathrm{H})$ results of altruism. Low scores among the respondents - both males and females - in terms of altruism are within the range $\leq 55$, whereas the high ones are within the range $\geq 85$. The group of respondents with low scores comprises 44 persons, the mean score $(\mathrm{M})$ for this group being 51.28 (SD $=11.02)$. The group of respondents with high scores comprises 40 persons, the mean score $(\mathrm{M})$ for this group being 94.14 (SD = 12.42). There is a statistically significant difference between the 
results achieved by both groups of students, where $\mathrm{F}=718.32$; $\mathrm{p}<0.001$.

The values obtained on the basis of the Purpose in Life Test (PLT) and the Value Survey (RVS) conducted among students with a high $(\mathrm{H})$ and low $(\mathrm{L})$ level of altruism were subjected to further analysis. In order to find significant differences between the two groups of students (university students with a high level of altruism and students with a low level of altruism) the analysis of variance (ANOVA) was carried out. For the variables expressed by ranks a non-parametric significance test (Mann-Whitney $U$ test) was applied. By interpreting the values preference, three top-most values in the highest and lowest rank were taken into consideration in the statistical description. The results were interpreted on the basis of the mean values (M) and standard deviations (SD). The existence of statistically significant differences enables to find answers to the study question: to what extent the level of altruism differentiates the variables of university students.

The procedure of the analysis of the multiple stepwise regression was also applied. This type of method has several functions: it aims at finding independent variables - so-called 'significant'; it describes the relation between an independent variable and a dependent variable (multiple regression coefficient - R); and it sets the percentage value of the explanatory variance of a dependent variable $\left(R^{2}\right)$, it shows the order in which independent variables are entered into the equation of the regression.

In order to get empirical material with help of which the research problem can be solved, an appropriate study among university students - males students of electrical engineering and philosophy, and female students of pedagogy and physics - was conducted. The survey was conducted in 2009-2010 in Kraków. The age of the respondents ranged from 21 to 25 . The survey was scheduled for after university classes. 200 sets of correctly completed questionnaires were used for the results analysis. 


\section{RESULTS ANALYSIS}

The analysis of the subject matter reveals that the level of altruism differentiates the students' world of terminal values personal and social in character and their meaning in life.

The results obtained in the Value Survey (RVS) concerning terminal values in the group with a high level of altruism reveal that the highest ranked were values such as wisdom (3.0), family security (4.0) and an exciting life (5.5) and the lowest ranked were self-respect (15.0), mature love (12.5) and pleasure (12.5), whereas in the group with a low level of altruism values such as an exciting life (5.0), family security (6.0) and freedom (7.0) were ranked highest, and lowest: a comfortable life (13.5), mature love (13.0) and social recognition (12.5).

The results concerning terminal values among people with a high level of altruism and those with a low level indicate that a statistically significant difference is noticeable in several ranking positions. People with a high level of altruism respect more family security $(\mathrm{u}=1118.0 ; \mathrm{p}<0.05)$, salvation $(\mathrm{u}=1183.5 ; \mathrm{p}<$ 0.05), happiness $(u=1087.5 ; p<0.05)$, a comfortable life $(u=973.0$; $\mathrm{p}=0.05)$ and wisdom $(\mathrm{u}=1058.0 ; \mathrm{p}<0.05)$ than young people with a low level of altruism, whereas the people with a low level of altruism respect more a world at peace $(\mathrm{u}=1000.5 ; \mathrm{p}<0.05)$, self-respect $(\mathrm{u}=953.0 ; \mathrm{p}<0.05)$ and inner harmony $(\mathrm{u}=918.5$; $\mathrm{p}<0.05)$ than those with a high level of altruism.

The results obtained in the Purpose in Life Test (PLT) suggest that there are statistically significant differences between the two groups of people in two dimensions of a sense of meaning in life. People with a higher level of altruism are characterized by a higher level of a sense of meaning in life $(\mathrm{SZ})(\mathrm{F}=4.50 ; \mathrm{p}<0.01)$ and purpose in life $(\mathrm{CZ})(\mathrm{F}=3.11 ; \mathrm{p}<0.05)$ than the young people with a low level of altruism. There is no statistically significant difference noticeable in the third factor, which concerns affirmation of one's own life. 
It was decided to show which of the terminal values have a significant influence on the sense of meaning in life in people with a high and low level of altruism. (See Table 1 for the results of the analysis).

Table 1. Independent variables concerning terminal values explaining the variance of meaning in life (a sense of meaning in life (SZ) - as a state of meaning in life, attainment of goals (CZ) and affirmation of life (DZ) - as a sign of accomplishment of the need of meaning in life)). Results of the analysis of the multiple stepwise regression among people with a high $(\mathrm{H})$ and low $(\mathrm{L})$ level of altruism.

\begin{tabular}{|c|c|c|c|c|}
\hline Groups & $\begin{array}{c}\text { Independent variable: Sense of } \\
\text { meaning in life }(\mathrm{SZ})\end{array}$ & B & $\mathrm{R}$ & $\begin{array}{c}\text { Percentage of } \\
\text { explained variance }\end{array}$ \\
\hline \multirow[t]{3}{*}{$\mathrm{H}$} & Social Recognition (9) & 0.07 & 0.4899 & 24 \\
\hline & True Friendship (1) & -0.06 & 0.6082 & 37 \\
\hline & Wisdom (10) & -0.05 & 0.6764 & 46 \\
\hline \multirow[t]{2}{*}{$\mathrm{L}$} & Social Recognition (9) & 0.10 & 0.4174 & 17 \\
\hline & $\begin{array}{l}\text { Independent variable: } \\
\text { Purpose in life }(\mathrm{CZ})\end{array}$ & $\mathrm{B}$ & $\mathrm{R}$ & $\begin{array}{c}\text { Percentage of } \\
\text { explained variance }\end{array}$ \\
\hline $\mathrm{H}$ & Salvation (11) & -0.09 & 0.5299 & 28 \\
\hline \multirow[t]{2}{*}{$\mathrm{L}$} & Social Recognition (9) & 0.09 & 0.3984 & 16 \\
\hline & $\begin{array}{l}\text { Independent variable: } \\
\text { Affirmation of one's own life (DZ) }\end{array}$ & $\mathrm{B}$ & $\mathrm{R}$ & $\begin{array}{c}\text { Percentage of } \\
\text { explained variance }\end{array}$ \\
\hline $\mathrm{H}$ & Wisdom (10) & -0.04 & 0.3797 & 14 \\
\hline \multirow[t]{2}{*}{$\mathrm{L}$} & Social Recognition (9) & 0.10 & 0.5379 & 29 \\
\hline & An Exciting Life (18) & 0.06 & 0.6569 & 43 \\
\hline
\end{tabular}

The four independent variables relating to final values reveal a significant influence on the sense of meaning in life (SZ) in the group of people with a high $(\mathrm{H})$ and low $(\mathrm{L})$ level of altruism. In the group of people with a high level of altruism $(\mathrm{H})$ three independent variables, relating to values such as social recognition (9), true friendship (1) and wisdom (10) proved to be significant. The first independent variable, namely social recognition (9), explains $24 \%$ of the variance of the dependent variable SZ $(R=0.4899)$, and all the independent variables together explain $46 \%$ of the variance 
of the dependent variable SZ $(\mathrm{R}=0.6764)$. The first independent variable has a positive relationship with the sense of meaning in life, whereas the others negative. The goodness of fit of the stepwise regression equation defines the F-test value $\mathrm{F}=7.03$; $\mathrm{df}=$ $3 ; \mathrm{p}<0.05$. In the group with a low level of altruism (L) only the variable relating to social recognition (9) counts. The variable in question explains $17 \%$ of the variance of the dependent variable (SZ) $(\mathrm{R}=0.4174)$. It has a positive relationship with the dependent variable. The goodness of fit of the stepwise regression equation defines the F-test value $\mathrm{F}=5.28 ; \mathrm{df}=1 ; \mathrm{p}<0.05$.

Two independent variables relating to terminal values reveal a significant influence on the purpose in life $(\mathrm{CZ})$ in the group of people with a high $(\mathrm{H})$ and low $(\mathrm{L})$ level of altruism. In the group of people with a high level of altruism $(\mathrm{H})$ the independent variable relating to salvation (11) proved to be significant. It explains $28 \%$ of the variance of the dependent variable $C Z(R=0.5299)$. It has a negative relationship with the dependent variable. The goodness of fit of the stepwise regression equation defines the F-test value $\mathrm{F}=10.54 ; \mathrm{df}=1 ; \mathrm{p}<0.05$. In the group with a low level of altruism (L) the variable relating to social recognition (9) counts. This variable explains $16 \%$ of the variance of the dependent variable $(C Z)(R=0.3984)$. It has a positive relationship with the dependent variable. The goodness of fit of the stepwise regression equation defines the F-test value $\mathrm{F}=4.72 ; \mathrm{df}=1 ; \mathrm{p}<0.05$.

Three independent variables relating to terminal values reveal a significant influence on the affirmation of one's life (DZ) in the group of people with a high $(\mathrm{H})$ and low $(\mathrm{L})$ level of altruism. In the group of people with a high level of altruism $(\mathrm{H})$ the independent variable relating to wisdom (10) proved to be significant. It explains $14 \%$ of the variance of the dependent variable DZ $(R=0.53797)$. It has a negative relationship with the dependent variable. The goodness of fit of the stepwise regression equation defines the F-test value $\mathrm{F}=4.55 ; \mathrm{df}=1 ; \mathrm{p}<0.05$. In the group with a low level of altruism (L), however, two variables relating 
to social recognition (9) and an exciting life (18) count. The former, that is social recognition (11), explains $29 \%$ of the variance of the dependent variable (DZ) $(R=0.5379)$, and the two of them together explain $43 \%$ of the variance of the dependent variable DZ $(R=0.6569)$. They have a positive relationship with the dependent variable. The goodness of fit of the stepwise regression equation defines the F-test value $\mathrm{F}=9.11 ; \mathrm{df}=2 ; \mathrm{p}<0.05$.

\section{CONCLUSIONS}

The analysis of the subject matter concerning the relationship between terminal values personal and social in character and meaning in life, i.e. a sense of meaning in life - as a state of meaning in life, attainment of goals and affirmation of one's own life - as a sign of accomplishment of the need of meaning in life, in groups of students with varied intensity of altruism indicates that each of those dimensions is important and significant and each of them performs an appropriate function in the whole of human existence.

1. The first hypothesis, which implies a relationship between meaning in life and the level of altruism among students, was almost fully confirmed. Students with a high level of altruism appear to have a higher level of meaning in life, i.e. a sense of meaning in life - as a state of meaning in life, and of attainment of life goals - as a sign of accomplishment of the need of meaning in life, than students with a low level of altruism. In the third factor, which refers to affirmation of one's own life there is only one tendency differentiating this dimension of meaning in life noticeable. In accordance with Miller's theory (2008) as well as with Śliwak and Król's studies (1989-1990), it was expected that students with a high level of altruism are also accompanied by a higher level of affirmation of one's own life. However, this failed to be confirmed in the present study. 
It would suggest that the level of affirmation of one's own life is, in this case, not significantly related with the intensity of altruism among university students.

2. The second hypothesis was only partly confirmed. It indicates a preference of terminal values personal and social in character in lives of students with a high level of altruism. Students with a high level of altruism seem to respect most values such as wisdom, family security and an exciting life. Two of them are personal values and one a social value. Moreover, the students in this group have claim least respect for values: self-respect, mature love and pleasure. Similarly, two of them are values personal in character and one social. It would suggest that students with a high level of altruism, out of terminal values, respect most values personal in character than social. This part of the hypothesis was not confirmed. It was expected - in accordance with the studies of other researchers (Staub, 1981; Śliwak, 2004) - that students with a high level of altruism - owing to its cognitive-social dimension - would respect more terminal values social in character rather than personal. However, the second part of the hypothesis was confirmed, which implies that students with a high level of altruism, out of terminal values prefer the least values personal in character, which had also been proven by other research (Staub, 1978; Allport, 1988).

3. Similarly, the third hypothesis, which indicates a preference of terminal values social and personal in character in lives of students with a low level of altruism, was only partly confirmed. Students with a low level of altruism value most things such as an exciting life, family security and freedom. Two of them concern values personal in character and one social. This group of students claims least respect for values: a comfortable life, mature love and social recognition. Again, two of them concern values personal in character and one social. Thus, this part of the hypothesis was confirmed. In accordance with other stud- 
ies (Staub, 1987; Davis, 1999), it was expected that students with a low level of altruism - due to their altruism having little intensity of social dimension - respect more terminal values personal in character rather than social. The second part of the hypothesis, though, which suggests that students with a low level of altruism prefer terminal values social in character least, was confirmed, also in other studies (Batson, 1998).

4. The fourth hypothesis, which indicates the contribution of terminal values to explaining the variance of meaning in life - as a state of meaning in life, in groups of students with a high and low level of altruism, was partly confirmed. Three terminal values, such as social recognition, true friendship and wisdom appear to contribute significantly to explaining the variance of a sense of meaning in life in a group of students with a high level of altruism. Two of them concern personal values and one social. However, only one terminal value contributes to explaining the variance of a sense of meaning in life in a group of students with a low level of altruism - namely a value personal in character: social recognition. It was expected, according to Popielski's (2008) and Miller's (2008) theory, that terminal values personal in character contribute to a greater extent to explaining the variance of a sense of meaning in life - as a state of meaning in life, in lives of students with a high intensity of altruism. It was also expected that, out of terminal values, values social in character are significantly related to a sense of meaning in life in a group of students with little intensity of altruism.

5. The fifth hypothesis, which suggests a contribution of terminal values to explaining the variance of meaning in life, i.e. attainment of life goals and affirmation of one's own life, which are a sign of accomplishment of the need of meaning in life in a group of students with a high and low level of altruism, was partly confirmed. Two values: social recognition and salvation significantly contribute to explaining the variance of a variable 
relating to meaning in life, i. e. attainment of life goals - the former in a group of students with a high level of altruism and the latter in a group with a low level thereof. Both of them concern values personal in character. In addition, three terminal values: wisdom, social recognition and an exciting life contribute to explaining the variance of meaning in life, i.e. affirmation of life - the first one in a group of students with a high level of altruism and the other two in a group with a low level thereof. All three concern personal values. The expectations were in accordance with Śliwak's (2001) and Popielski's (2008) studies, which suggest that values social in character have a stronger relationship with meaning in life - that is attainment of life goals and affirmation of life in a group of students with a high level of altruism than in a group with a low level thereof, due to its cognitive-social dimension.

Students with a high and low level of altruism do not seem to differ in terms of the kind of values they respect in their lives in explaining the variance of meaning in life, i.e. a sense of meaning in life - as as a state of meaning in life, and attainment of life goals as well as affirmation of life - as a sign of accomplishment of the need of meaning in life. The most respected terminal values, and simultaneously the strongest ones contributing to explaining the variance of meaning in life, turned out to be values personal in character, both in a group of students with a high and low level of altruism. The data analysis implies that lower assessment of social values than personal ones may be a more important reason for engaging in altruistic behaviour.

The analysis of the present study indicates that a terminal value personal in character - social recognition is the strongest predicator of meaning in life, i.e. a sense of meaning in life - as a state of meaning in life, in a group of students with a high and low level of altruism, whereas in a group of students with a low level of altruism - attainment of life goals and affirmation of life - as a sign of accomplishment of the need of meaning in life. 
It would suggest that this particular terminal value personal in character is significantly related to meaning in life as well as the intensity of students' altruism. It is in agreement with Frankl's (1987) theory, which postulates that people who enjoy high social recognition feel needed and, at the same time, reveal a greater sense of meaning in life and are accompanied by considerable care about the welfare of other people.

\section{FINAL CONCLUSIONS}

This analysis of the subject matter, aiming at showing the relationship between terminal values personal and social in character and meaning in life, i.e. a sense of meaning in life - as a state of meaning in life, attainment of goals and affirmation of one's own life - as a sign of accomplishment of the need of meaning in life, in groups of students with a high and low level of altruism in the present period of socio-cultural change, implies several conclusions.

1. There exists a significant correlation between terminal values personal and social in character and meaning in life, i.e. a sense of meaning in life, attainment of goals and affirmation of one's own life, in groups of students with varied intensity of altruism.

2. Out of terminal values, personal values are the strongest variables which contribute to explaining the variance of meaning in life, i.e. a sense of meaning in life, attainment of life goals and affirmation of one's own life, in groups of students with varied intensity of altruism.

3. The analysis of the subject matter indicates that all variables taken into consideration in this paper are autonomic in their cognitive, emotional, evaluative and aspiring dimensions, however, they constitute an integrity of human existence. They 
decide about students' cognitive-social development as well as the way they experience their existence.

4. The present analysis of the subject matter can make a contribution to more detailed empirical studies. Many questions are still left with no answer, e.g. the one concerning the relationship between values and other, not studied so far elements of personality; the place of altruism in a human life; or the role of one's own activity in discovering meaning in life and its accomplishment.

\section{REFERENCES}

Adler, A. (1964). Understanding Human Nature. New York: Greenberg Publisher. Allport, G. (1988). Osobowość i religia. Warszawa: PAX.

Aronson M., Wilson T., Akert R. (1997). Psychologia społeczna. Poznań. Zysk i S-ka. Batson, C. (1998). Altruism and prosocial behavior. In: Gilbert, D., Fiske, S., Lindzey, G. (red.), The handbook of social psychology, pp. 282-316. Boston: McGraw Hill. Blanchard, K. (1998). Zarzadzanie poprzez wartości. Warszawa: Studio Emka. Brzozowski, P. (2007). Wzorcowa hierarchia wartości. Lublin: Wyd. UMCS. Buksik, D. (2003). Wrażliwość sumienia (studium empiryczne). Warszawa: Centrum Medyczne Pomocy Psych-Ped.

Cieciach, J. (2006). Rodzina w systemie wartości oraz w kontekście przekonań światopoglądowych młodzieży. Psychologia. Edukacja i Społeczeństwo, 3, 121137.

Czerniawska, M. (2000). Agresja a system wartości. In: Derbis, R. (red.), Jakość rozwoju a jakość życia, pp. 353-364. Częstochowa: WSP.

Davis, M. (1999). Empatia: O umiejętności wspótodczuwania. Gdańsk: GWP.

Frankl, V. (1971). Homo patiens. Warszawa: PAX.

Frankl, V. (1977). Fundamenti a applicazioni della logoterapia. Torino: Boringhieri. Frankl, V. (1978). Psychologia dla każdego. Warszawa: PAX.

Frankl, V. (1987). La sofferenza di una vita senza senso. Torino: Boringhieri.

Głaz, S. (2002). Doświadczenie religijne a sens życia. Kraków: WAM.

Głaz, S. (2006), Sens życia a religia. Wymiary filozoficzno-psychologiczne. Poznań: Fundacja Humaniora.

Głaz, S. (2010). Rola Kościoła w integralnym rozwoju młodzieży. Kraków: WAM. 
Głaz, S. (2011). Osobowościowe uwarunkowania przeżycia religijnego młodzieży studiującej. Kraków: WAM.

Jarymowicz, M. (2004). Tożsamościowe przestanki otwartości na innych i zachowań altruistycznych. In: Cuda, J. (red.), Społeczna aktualizacja tożsamości człowieka, pp. 1-18. Katowice: Księgarnia św. Jacka.

Jones, R. (2001). Psychological Value and Symbol Formation. Theory and Psychology, 2, 233-254.

Karyłowski, J. (1982), O dwóch typach altruizmu. Badania nad endo- $i$ egzocentrycznymi źródłami podejmowania bezinteresownych działań ma rzecz innych ludzi, Warszawa: PAN.

Korchmaros, J., Kenny, D. (2001), Emotional closeness as a mediator of the effect of genetic relatedness on altruism, Psychological Science, 12, 262-265.

Kość, A. (2008). Relacja prawa i wartości w spoteczeństwie demokratycznym. In: Popielski, K. (red.), Wartości dla życia, pp. 205-217. Lublin: Wyd. KUL.

Kruger, D. (2001), Psychological aspects of adaptations for kin directed altruistic helping behaviors, Social Behavior and Personality, 29, 323-330.

Loewenthal, K. (2002). Are Women More Religious than Men? Gender Differences in Religious Activity Among Different Religious Groups in the UK, Personality and Individual Differences, 32, 133-140.

Lukas, E. (1990). Geist und Sinn. Logotherapie - die dritte Wiener Schule der Psychotherapie. Monachium: Psychologie Verlags Union.

Łobocki, M. (1998). Altruizm a wychowanie. Lublin: Wyd. UMCS.

Maraiński, J. (2001). Kryzys moralny czy transformacja wartości? Lublin: TN KUL. Maslow, A. (1968). Toward a Psychology of Being. New York: Van Nonstrand Reinhold.

May, R. (1981). Freedom and Destiny. Now York: Norton.

Miller, A. (2008). Dobro i zło. Z prespektywy psychologii społecznej. Kraków: WAM.

Oleś, P. (2003), Wprowadzenie do psychologii osobowości, Warszawa: Scholar.

Oliynichuk, S., Popileski, K. (2008). Wartości moralne a poczucie sensu życia. In: Popielski, K. (red.), Wartości dla życia, pp. 499-520. Lublin: Wyd. KUL.

Olsen, D. (1991). Empathy as an Ethical and Philosophical Basis for Nursing, Journal of Advanced Nursing, 14, 62-76.

Opoczyńska, M. (1995). Człowiek wobec wartości. In: Gałdowa, A. (red.). Wybrane zagadnienia z psychologii osobowości, pp. 169-186. Kraków: UJ.

Piliavin, J., Charng, H. (1990). Altruism: A review of recent theory and research, Annual Review of Sociology, 16, 27-65.

Piontek, F. (2008), Depozyt niezrealizowanych wartości a proces rozwoju społecznogospodarczego. In: Popielski, K. (red.), Wartości dla życia, pp. 137-162. Lublin: Wyd. KUL. 
Popielski, K. (1987). Testy egzystencjalne: Metody badania frustracji egzystencjalnej i nerwicy noogennej. In: Popielisk, K. (red.), Człowiek - pytanie otwarte, pp. 237-261. Lublin: Red. Wyd. KUL.

Popielski, K. (2008). Psychologia egzystencji. Wartości w życiu. Lublin: Wyd. KUL. Rogers, C. (1983). Un modo di essere. Firenze: Psycho-di Martinelli.

Rokeach, M. (1973). The Nature of Human Values. New York: Free Press.

Staub, E. (1978). Positive social behavior and morality. Social and personal influences. New York: Academic Press.

Śliwak, J. (1994), Poziom altruizmu a obraz siebie. Badania empiryczne dorastającej młodzieży, Roczniki Filozoficzne KUL, 4, 119-163.

Śliwak, J. (2001). Osobowość altruistyczna. Lublin: Fundacja Wydawnictwa KUL. Śliwak, J. (2002). Niepokój a poziom altruizmu, Przegląd Psychologiczny, 2, 229245.

Śliwak, J., Król, A. (1989-1990). Poziom altruizmu a poczucie sensu życia, Roczniki Filozoficzne KUL, 4, 198-210.

Śliwak, J., Leszczuk, P. (1994), Poziom altruizmu a obraz siebie. Badania empiryczne dorastającej młodzieży, Roczniki Filozoficzne KUL, 4, 119-164.

Velmans, M. (2000). Understanding Consciousness. London: Routledge. 